\title{
Reevaluating the Sociotropic Economic Voting Hypothesis
}

\author{
Thomas G. Hansford \\ *** Corresponding Author *** \\ Associate Professor of Political Science \\ School of Social Sciences, Humanities and Arts \\ University of California, Merced \\ 5200 North Lake Road \\ Merced, CA 95343 \\ USA \\ Phone: 1-209-725-8784 \\ Email: thansford@ucmerced.edu \\ Brad T. Gomez \\ Associate Professor of Political Science \\ Department of Political Science \\ Florida State University \\ 536 Bellamy Building \\ Tallahassee, FL 32306-2230 \\ USA \\ Email: bgomez@,fsu.edu
}




\section{Reevaluating the Sociotropic Economic Voting Hypothesis}

One of the canonical causal claims in political science links individuals' evaluations of the national economy with their votes. Yet there are reasons to expect that these economic perceptions are endogenous to vote choice, meaning that existing cross-sectional models cannot provide a valid test of the causal retrospective voting claim. Using an instrumental variables approach, we assess the effect of sociotropic evaluations on the decision to vote for the incumbent president or his party's candidate in eight recent U.S. presidential elections. In contrast with prior work, our results reveal that while there is a correlation between sociotropic evaluations and vote choice, individuals' subjective evaluations only exert a causal effect on votes when there is not an incumbent president on the ballot. These results suggest that, when incumbents are on the ballot, individuals' economic perceptions are particularly clouded by appraisals of the incumbent and thus do not operate as an exogenous influence on votes.

Keywords: economic voting; retrospective voting; sociotropic evaluations; U.S. presidential elections 


\section{Introduction}

In a discipline with a relative dearth of ironclad empirical regularities, economic voting stands out as one of political science's most replicated, accepted, and influential findings (see LewisBeck and Stegmaier 2000). Decades-worth of research convincingly suggests a robust connection between economic variables and vote choice in U.S. elections (e.g., Kramer 1971; Lewis-Beck 1988; Lewis-Beck and Paldam 2000; Markus 1988). Numerous studies of electoral choice in other countries also support the existence of economic voting (e.g., Gomez and Wilson 2006; Lewis-Beck 1988), though this relationship may be conditioned by how institutional arrangements clarify partisan responsibility (Duch and Stevenson 2008; Powell and Whitten 1993; Tilley, Garry, and Bold 2008) and the amount of welfare spending (Pacek and Radcliff 1995). This apparent connection between economic conditions and votes for the incumbent party has substantial implications for democratic theory. By suggesting that incumbent governments are held responsible for economic performance, election-induced accountability seems plausible.

Economic voting studies vary in terms of the specific economic factors included in models of vote choice, but the general consensus is that self-reported retrospective evaluations of the national economy are the best economic predictor of individual-level votes (Lewis-Beck and Paldam 2000). ${ }^{1}$ Economic voting of this type is labeled "sociotropic voting" and suggests that voters are concerned with the economic well-being of the nation as a whole and not simply their personal financial situation (Kinder and Kiewiet 1981). In U.S. presidential elections, for example, voters reporting that the national economy has worsened are more likely to vote against the president (or

\footnotetext{
${ }^{1}$ Deviations from this consensus include studies focusing on prospective economic evaluations (e.g., Lockerbie 1992) and retrospective pocketbook evaluations (e.g., Markus 1988).
} 
his party), while voters who indicate that the economy has improved are more likely to vote for the incumbent (e.g., Kinder, Adams, and Gronke 1989).

But how do voters form their evaluations of the national economy? While past economic performance may play a part in their construction (e.g., Lewis-Beck 1988; Wlezien, Franklin, and Twiggs 1997), it is also likely that subjective evaluations are partially driven by voters' attachments to the incumbent candidate or party. Whether due to selective perception or by motivated reasoning (e.g., Bartels 2002; Taber and Lodge 2006; Gaines et al. 2007), voters may exaggerate the soundness of the economy when they intend to vote for the incumbent candidate/party and negatively evaluate the economy when they intend to vote otherwise. There is thus reason to expect that self-reported evaluations of the economy are endogenous to vote choice (e.g., Erikson 2004; Fiorina 1981). This is not a trivial concern, as it calls into question the countless individual-level models of retrospective voting that rely on subjective economic evaluations and thus render one of the canonical findings in political science suspect.

As our discipline has become less willing to ignore endogeneity and other threats to causal inference, a lively debate has ensued regarding the presence and consequences of economic voting. A pair of recent studies (Evans and Anderson 2006; Evans and Pickup 2010) use structural equation modeling with panel data and find that attitudes toward the incumbent party affect retrospective evaluations of the economy and that retrospective evaluations matter less than previously reported. Lewis-Beck, Nadeau, and Elias (2008), however, critique these authors' approach and using a combination of panel data and instrumental variables find support for the importance of sociotropic voting. The instruments used in this study are unsatisfactory though (Evans and Pickup 2010), and it remains unresolved whether the inferences of traditional models of sociotropic voting are valid. The extent to which there is a causal relationship between individual-level subjective economic evaluations and vote choice-despite abundant correlative evidence-remains an open question. 
We seek to provide a novel test of the effect of economic perceptions on vote choice using individual-level cross-sectional data. We begin by noting that while objective national economic conditions are plausibly exogenous to vote choice, individual-level perceptions of the economy are more theoretically relevant for explaining votes since the hypothesized causal mechanism occurs at this level. These individual-level evaluations are also analytically enticing owing to their crosssectional variation. But, to the extent that these perceptions are a function of respondents' attachment to the incumbent president or party, traditional estimates of the relationship between sociotropic evaluations and vote choice may be biased. We thus propose an instrument for retrospective sociotropic evaluations_changes in objective local economic conditions. These local conditions are exogenous to individual vote choice and predict individuals' subjective perceptions of the national economic situation. Using an instrumental variables approach, we assess the effect of sociotropic evaluations on the decision to vote for the incumbent president or candidate of the president's party in eight recent U.S. presidential elections. Despite a strong correlation between sociotropic evaluations and vote choice, we only find evidence of a causal link between these evaluations and vote choice when there is not an incumbent on the ballot. Counter to conventional wisdom, prior studies, and, frankly, our own expectations, we find no evidence that subjective economic assessments affect cross-sectional variation in vote choice when a president is seeking reelection. These results suggest that when incumbents are on the ballot economic perceptions are clouded by appraisals of the incumbent and thus do not operate as an exogenous influence on votes.

\section{Retrospective Voting}

In The Responsible Electorate, Key $(1966,61)$ writes of "the electorate in its great, and perhaps principal, role as an appraiser of past events, past performance, and past actions. It judges retrospectively." Over time, political science has come to accept the wisdom of Key's retrospective voting hypothesis. Voters look to the past to make judgments about the future, and, in turn, they 
reward or punish incumbent governments. Indeed, this hypothesis serves as a central assumption in various normative models of democratic accountability, where governments act as good agents because voters hold them responsible for their performance at election time (e.g., Fearon 1999). Following Key's retrospective voting hypothesis, Fiorina (1981) argues that information about past economic performance is paramount in voters' minds. When the economy is good, the incumbent is rewarded with votes; when the economy is bad, votes for the incumbent are withheld. For both Key and Fiorina the economic information most relevant for voters was the state of their personal financial circumstances (i.e., a "pocketbook" heuristic), though the retrospective pocketbook voting hypothesis has subsequently received scant empirical support both in the U.S. electorate (e.g., Markus 1988) and abroad (e.g., Lewis-Beck 1988). ${ }^{2}$

An alternative to the retrospective pocketbook voting hypothesis is offered by Kinder and Kiewiet (1981), who argue that voters are more concerned with changes in the collective welfare than personal considerations when voting. This retrospective sociotropic voting hypothesis states that voters who believe that the national economy has improved over the incumbent's previous term will vote to reelect him/her, while those who believe the national economy has worsened will vote against the incumbent. The evidence overwhelmingly seems to support this claim. While pocketbook effects are negligible in most studies of individual vote choice, sociotropic evaluations have been shown to have a substantial effect on voting decisions (e.g., Kiewiet 1983). Indeed, the weight of evidence in support of the sociotropic hypothesis over the pocketbook hypothesis is so

\footnotetext{
${ }^{2}$ As noted by Gomez and Wilson $(2003,272)$, “most of Fiorina's evidence for pocketbook voting comes from indirect effects, with personal economic experiences affecting general economic assessments, presidential evaluations, and partisanship.”
} 
one-sided that it is fair to say that when political scientists today think about "retrospective voting" they are more than likely thinking "sociotropic voting."

\subsection{The Appeal of Sociotropic Evaluations}

A central concern of the individual-level studies of economic voting is the effect of subjective evaluations of the national economy on vote choice. There are both theoretical and practical reasons for this focus. ${ }^{3}$ In individual-level models of presidential vote choice, the most appropriate and proximate economic variables are the voters' subjective evaluations of national economic performance_- "appropriate" with regard to level of analysis; "proximate" in that national economic conditions are easily and commonly attributed (even if not correctly so) to the incumbent president (see Gomez and Wilson 2001). Thus, to the extent that the state of the national economy affects presidential votes, it is likely through voters' economic perceptions.

Fundamentally, the key causal claim forwarded in the economic voting literature assumes that voters make their choices based on their perception of the state of the national economy. Yet-despite its pervasiveness—statistical models estimating the effect of objective national conditions on either individual or aggregate votes do not allow for a clean test of this causal claim. Importantly, a relationship between objective national conditions and votes could be explained by causal mechanisms other than retrospective voting. For example, in a weak party system such as that of the U.S., the emergence of strong candidates for office might be affected by the state of the economy if politicians simply believe in the existence of economic voting (Jacobson 1989). Alternatively, in parliamentary democracies, the timing of elections may coincide with fluctuations in economic performance (e.g., Smith 2003). Thus, subjective individual-level perceptions of the

\footnotetext{
${ }^{3}$ Stevenson and Duch (2013) make a strong case for the theoretical importance of sociotropic perceptions.
} 
economy may be theoretically preferable in these models because they offer a more direct test of the causal mechanism implied by the retrospective voting hypothesis.

In addition to the theoretical advantages of focusing on individual-level perceptions of the economy, there are also practical data limitations that can make objective economic conditions less useful in models of individual vote choice, particularly for studies focusing on a specific nation. As Markus (1988) notes, studies focusing on a single election cannot examine the effect of objective national conditions because these conditions do not vary between voters. Studies that attempt to overcome this limitation by pooling together individual-level data over multiple U.S. presidential elections can only include a small set of elections, due to historical limits on the availability of survey data. Thus, the key objective national economic indicators cannot vary to the degree that would be desired. Designs of this sort also limit the ability to control for other election-specific effects that might confound the observed relationship between objective national conditions and vote choice. Ideally, researchers would include election-specific fixed effects to deal with this issue, but this proves problematic when the key independent variables only vary between elections. Perceptions of the economy, on the other hand, vary between voters for a given election and thus offer the promise of greater empirical traction.

To illustrate the utility of leveraging the cross-sectional variation in subjective perceptionsand, more importantly, to provide apparent empirical support for the sociotropic hypothesis, Table 1 presents basic probit models of individual-level vote choice in U.S. presidential elections. The individual-level data employed throughout this paper are from the Cumulative Data File of the American National Election Study. ${ }^{4}$ While the Cumulative Data File contains survey information

\footnotetext{
${ }^{4}$ The 1948-2008 ANES CUMULATIVE DATA FILE was produced and distributed by Stanford University and the University of Michigan, 2010. These materials are based on work supported by
} 
for presidential elections dating back to 1948, our data are limited to eight recent elections (1980, 1984, 1988, 1992, 1996, 2000, 2004, and 2008) —all studies in which the retrospective sociotropic question was asked. $^{5}$

\section{[Table 1 Here]}

The dependent variable is the intention to vote for the incumbent president or the candidate of the incumbent president's party. Sociotropic Evaluation is the ANES 5-point scale on which low values represent the voter's perception that the economy has worsened and high values indicate perceptions of improvement. In light of evidence that retrospective voting is strongest in elections with an incumbent candidate (e.g., Miller and Wattenberg 1985; Nadeau and Lewis-Beck 2001; Norpoth 2002), we interact Sociotropic Evaluation with a dummy variable indicating whether the president is on the ballot (Incumbent Candidate). The model seeks to isolate further the apparent "effect" of Sociotropic Evaluation by including election fixed effects. These fixed effects account for election-to-election variation in the baseline probability of voting for the incumbent candidate or party. ${ }^{6}$ The model includes a number of standard individual-level control variables: Party ID, Personal

the National Science Foundation under Grant Nos. : SBR-9707741, SBR-9317631, SES-9209410, SES-9009379, SES-8808361, SES-8341310, SES-8207580, and SOC77-08885. Any opinions, findings and conclusions or recommendations expressed in this paper are those of the authors and do not necessarily reflect the views of the ANES or its funding organizations.

${ }^{5}$ The 2012 ANES is excluded because county codes were not available for request at the time of this study.

${ }^{6}$ Because national economic conditions are subsumed by these election fixed effects, objective economic variables are necessarily excluded from this model. 
Income, Education, Unemployed, Black, Female, and Age. $^{7}$ Each of these variables is interacted with Democratic Incumbent, which allows the effect of each variable to vary depending upon the party of the incumbent president. $^{8}$

The results in Table 1 appear to support strongly the importance of individual-level Sociotropic Evaluations. The estimate for this variable is positive and significant, as is the estimate for Sociotropic Evaluation $\times$ Incumbent Candidate. These estimates suggest that the better the respondent's evaluation of the economy, the more likely the respondent is to vote for the incumbent party. Consistent with prior research, this effect appears to be particularly pronounced when the incumbent president is seeking reelection. In fact, the z-statistics for the Sociotropic Evaluation variables are larger than those for any of the other independent variables in these models (including the election effects), with the exception of Party ID and Black. Not only is the use of subjective evaluations of the economy theoretically and practically appealing, it appears that there is strong evidence for this form of retrospective voting. Importantly, this apparent relationship is present despite the inclusion of

\footnotetext{
${ }^{7}$ Party ID is measured on a seven-point scale; low (high) values associated with Democratic (Republican) identification. Personal Income is a five-point scale indicating the respondent's family income percentile. Missing values of Personal Income were imputed (8.4\% of the observations, details available from the authors). Education is a seven-category scale of the respondents' educational attainment. Unemployed, Black, and Female are dummy variables. Age is measured in years.

${ }^{8}$ Respondent ideology is excluded from our models because $25.8 \%$ of ANES respondents do not assign themselves an ideological position. Eliminating these missing respondents_-via listwise deletion — from our study would be problematic since they may be less politically sophisticated and thus the subset of the voting population most likely to vote in a retrospective manner (Gomez and Wilson 2001). We therefore exclude ideology from the models reported here.
} 
election-specific fixed effects, which account for the variance between the respective cross-sections, including variance attributed to differences in objective national economic conditions.

\subsection{The Problem with Sociotropic Evaluations}

Given the apparent importance of subjective evaluations of the national economy, it is surprising that relatively few studies directly address the formation of these evaluations. In fact, Lewis-Beck and Paldam's $(2000,114)$ “stylized fact number 9" regarding the economic voting literature is that "[1]ittle is known about the macroeconomic knowledge of voters and how it is obtained" (but see Duch, Palmer, and Anderson 2000; Hetherington 1996). This is particularly worrisome given the lingering concerns regarding the potentially spurious nature of the relationship between subjective evaluations and vote choice (e.g., Evans and Anderson 2006; Kramer 1983; Markus 1988).

While it is likely that objective national economic conditions have an effect on subjective evaluations of the economy, it is also likely that these evaluations are influenced by variables that have little to do with the state of the economy. If the ultimate goal is to estimate the effect of subjective economic evaluations on vote choice, variables that influence both economic evaluations and votes will be particularly problematic. Dating back to Campbell et al. (1960), scholars have noted that partisanship affects how voters perceive the world and there is evidence of partisan bias in self-reported evaluations of the state of the economy (Duch, Palmer, and Anderson 2000). ${ }^{9}$ If Republican voters, for example, are more likely to evaluate the national economy positively when there is a Republican president, then even if there is no causal connection between their evaluations

\footnotetext{
${ }^{9}$ Partisan biases in assessments of the economy occur also in other democracies, though they are conditioned by the extent to which the country has a system that clarifies who is responsible for the economy (Parker-Stephen 2013).
} 
and their vote choice there may nonetheless be a correlation, assuming the researcher cannot perfectly measure and control for partisanship. In addition to partisanship-induced selective perception, voters may subconsciously alter their economic evaluations to make them consistent with their vote choice in an effort to reduce cognitive dissonance (Anderson, Mendes, and Tverdova 2004). Other less-overtly political variables, such as personal income might also predict both economic evaluations and vote choice.

In sum, subjective economic assessments are not simply a combination of objective national economic conditions, which are captured by the election fixed effects, and an idiosyncratic "error term,” as suggested by Kramer (1983). Instead, these evaluations vary systematically based on variables that are viewed as determinants of vote choice. If researchers could perfectly account for all factors that affect both retrospective evaluations and vote choice, then endogeneity would not pose a problem. However, a perfectly specified model with perfect data is unlikely to exist. It is much more likely that unmeasured or unobserved determinants of retrospective evaluations exist in these models and that they correlate with vote choice. This endogeneity will bias the estimates in retrospective voting models and detract from the ability to make causal inferences about individuallevel economic voting.

\subsection{Addressing Endogeneity in Models of Retrospective Voting}

While there is tacit acknowledgment of potential endogeneity in models of economic voting, until recently few studies have attempted to address the problem. Instead—it should be emphasized-most research proceeds as if evaluations of the state of the economy are exogenous to vote choice. Among studies attempting to address potential endogeneity, there have been two general approaches. Some scholars simply use objective national economic conditions as their key independent variables in voting models (e.g., Markus 1988, van der Brug, van der Eijk, and Franklin 2007). We have already noted the limitations of this approach, though when a large number of 
elections can be analyzed, such as in cross-national studies (e.g., Tilley, Garry, and Bold 2008), this approach is useful.

A second approach is to use structural equation modeling of panel data to leverage over-time variation in individuals' evaluations of the economy and vote preferences. This "within-individuals over time" modeling approach is particularly good at controlling for endogeneity that results from "time-varying characteristics of individuals that predict both economic evaluations and approval" (Pickup and Evans 2013, 739). In this vein, Evans and Anderson (2006, 194) "model the dynamic relationship between party support and retrospective economic perceptions" using the 1992-97 British Election Panel Study and show that individuals' subjective evaluations of the economy are largely a function of prior sentiments toward the incumbent Conservative Party. Evans and Pickup (2010) use panel data from the 2000-2002-2004 ANES panel study to estimate the dynamic relationship between retrospective sociotropic evaluations and political preferences, including measures of approval, partisanship, and the vote. The three-wave panel allows the authors to use second lags of the economic evaluations and political preferences as instruments for individuals' “current” assessments and preferences. Their findings suggest a clear causal dynamic; "individuals' perceptions of the macro economy do not explain their political preferences, in fact the direction of causality is reversed: economic perceptions are derived from political preferences" (Evans and Pickup 2010, 1247).

This dynamic modeling approach offers a solution to endogeneity resulting from changes in an individual's attitudes over time. Yet this approach is not feasible if the analysis is limited to crosssectional data lacking a panel component — the most common structure of individual-level voting data. Cross-sectional data allows the researcher to test the effect of retrospective sociotropic evaluations on vote choice by examining differences between individuals (rather than within individuals). In these situations, a potential solution to the endogeneity problem is to find a suitable 
instrument for retrospective sociotropic evaluations that accounts for contemporaneous differences between individuals. Generally speaking, it has been challenging to develop proper instruments for sociotropic evaluations (Fraile and Lewis-Beck 2010; Lewis-Beck, Nadeau, and Elias 2008). For example, subjective pocketbook evaluations and various demographic variables have been employed as instruments (Lewis-Beck, Nadeau, and Elias 2008; Lewis-Beck, Stubager, and Nadeau 2013), though the former is likely to be just as endogenous as subjective sociotropic evaluations and the latter violates the exclusion restriction necessary to properly identify an instrumental variables model. ${ }^{10}$ Scholars have also used objective national conditions as instruments for subjective perceptions (Nadeau, Lewis-Beck, and Belanger 2013), but this approach cannot account for individual-level variation in sociotropic perceptions.

\section{Local Economic Conditions as an Instrument for Sociotropic Evaluations}

An instrument for subjective economic assessments needs to be clearly exogenous to vote choice and successfully predict these assessments. We believe that objective local economic conditions satisfy these criteria. Specifically, we use $\Delta$ County Income and $\Delta$ County Unemployment as instruments for Sociotropic Evaluation. ${ }^{11}$ The former variable is measured as the change in the

${ }^{10}$ The exclusion restriction requires that the excluded instrument not directly cause the dependent variable in the main equation, which is vote choice in this context. Demographic variables such as race and class (e.g., Lewis-Beck, Nadeau, and Elias 2008) likely violate this restriction and thus should not be viewed as excluded instruments. This type of demographic variable can, of course, be included in first stage models if they are also then included in the second stage and other variables serve as excluded instruments.

${ }^{11}$ The respondent's county of residence is not made publicly available by the ANES for more recent elections. A Restricted Data Access Application was made to in order to obtain this variable. 
inflation-adjusted median income in the survey respondent's county of residence since the last presidential election (in $\$ 1,000 \mathrm{~s}$ ). The latter is measured as the change in the unemployment rate in the respondent's home county since the last presidential election. ${ }^{12}$

Local economic conditions are an attractive instrument for perceptions of national economic conditions for two reasons. First, local economic conditions vary considerably for any given presidential election, offering the potential for explaining variation in individual-level assessments of the national economy for a particular election. Objective national economic conditions cannot explain this variation. Second, because these variables measure objective conditions, each should be exogenous to individual votes. Unlike survey respondents' self-reported perceptions of the national economy, $\Delta$ County Income and $\Delta$ County Unemployment will not be contaminated by individuals' partisan screens, affect for the president, or attempts to reduce cognitive dissonance.

That these two county-level variables predict voter evaluations of the state of the national economy may be less immediately obvious. It makes theoretical sense, though, for voters to use local, tangible, and easily accessible economic information to make inferences about the state of the national economy (see Books and Prysby 1991, 146). This is consistent with what psychologists refer to as the "availability heuristic," which is the tendency for people to use readily available information to make inferences about distant phenomena (see Nisbett and Ross 1980, 18-23). ${ }^{13}$

\footnotetext{
${ }^{12}$ County-level unemployment data are from the Bureau of Labor Statistics. County-level per capita personal income data were provided by the Bureau of Economic Analysis (http://www.bea.gov/iTable/iTable.cfm?reqid=70\&step=1\&isuri=1\&acrdn=5).

${ }^{13}$ An individual's personal economic circumstances are even more available than local economic conditions. There is little evidence, however, that personal economic variables influence reported perceptions of the state of the national economy (see the Online Appendix).
} 
Indeed, Weatherford (1983) provides evidence of a correlation between local-level unemployment and perceptions of the state of the national economy in 1978.

To determine if Weatherford's result generalizes beyond his single time point, we again utilize ANES data for the 1980 though 2008 U.S. presidential elections and estimate a model of Sociotropic Evaluation. We include our two county-level objective economic variables as independent variables, along with all the control variables from the Table 1 model and the election fixed effects. Because the model includes election fixed effects, the estimates for the county-level economic variables reflect the effect of these variables on perceptions of the national economy after any effect of the true state of the national economy, the average state of the county economies, or media portrayals of the economy (Hetherington 1996) has been removed.

One potential concern with using county-level economic conditions as an instrument for sociotropic evaluations in vote choice models is that there could be some sort of correlation between the partisan nature of a county and changes to its economic conditions. Moreover, any effect of the partisan nature of a county might depend upon the partisanship of the incumbent president. For example, it could be the case that Democratic counties do worse under Republican presidents (and vice versa), due to differences in economic policy and the types of county benefited or harmed by these differences. To control for this potential problem in both this model and, more importantly, in the full instrumental variable model estimated below, we include two additional independent variables: County Republican Vote $e_{t-1}$ and County Republican Vote $e_{t-1} \times$ Democratic Incumbent. The former consists of the two-party vote share (as a percentage) of the Republican presidential candidate in the respondent's county in the previous election, while the latter interacts this vote share with the presence of a Democratic president. Table 2 displays the results for the model estimated with ordered probit (Model 2.1) and OLS (Model 2.2).

[Table 2 Here] 
In Model 2.1, the estimate for $\Delta$ County Income is positive and statistically significant. As the average local income increases, respondents are more likely to view the state of the national economy as improved. Local unemployment also appears to shape subjective assessments of the national economy. The estimate for $\Delta$ County Unemployment is negative and significant, revealing that increases in local-level unemployment lead respondents to report more negative views of the state of the national economy. We should emphasize that these results are obtained while controlling for the actual state of the national economy with election fixed effects.

The results in Table 2 support our claim that voters use local economic conditions to make inferences about the state of the national economy. On its own merits, this is a compelling finding for it suggests that cross-sectional variation in individuals' subjective evaluations of the national economy is not simply a product of random perceptual errors (Erikson 2004; Kramer 1983) but, instead, reflects voters use of local, accessible information to make inferences about the national economy.

The highly significant relationship between the objective, exogenously-determined local economic conditions and individuals' Sociotropic Evaluations is also crucial for our implementation of an instrumental variables design. To assess whether these results change when shifting estimators from ordered probit to OLS, which will be necessary for the IV model we estimate, Model 2.2 presents the results of the model obtained with OLS. The results for both county-level economic variables are robust to this change in estimator. Both coefficient estimates remain statistically significant and a joint F-test of $\Delta$ County Income and $\Delta$ County Unemployment produces a statistic of 
24.4, well above the econometric rule of thumb $(F=10)$ for a set of excluded instruments (see Staiger and Stock 1997). ${ }^{14}$

Before proceeding further with these instruments, it is useful to consider whether "variation in the endogenous regressor related to [our] instrumental variable [has] the same causal effect as variation unrelated to [our] instrument" (Dunning 2008, 291). Sociotropic evaluations (SE) can be conceptually divided into two components, $S E_{1}$ and $S E_{2}$, where the former includes all variation in evaluations that has the same effect on vote choice as the variation exogenously-determined by local economic conditions, and the latter includes variation in sociotropic evaluations that has some alternative effect. How much variation is contained by each component? At one extreme, $S E_{1}$ could consist only of variation in sociotropic evaluations determined by local economic conditions. At the other extreme, $S E_{1}$ could contain all the exogenous variation in $S E$, meaning that our IV estimates represent the causal effect of any and all variation in sociotropic evaluations on vote choice. While perhaps neither extreme is realistic, we believe there is strong reason to expect that $S E_{1}$ contains much if not close to all of the exogenous variation of $S E$. There is simply little reason to expect that variation in sociotropic evaluations due to the state of the local economy has a fundamentally different effect on vote choice than any other genuine source of variation in these evaluations. Objective local economic conditions should allow us to identify the general effect of variation in sociotropic evaluations on vote choice.

\footnotetext{
${ }^{14}$ If we replace the four-year change in a county's economic state with a one-year change, the county-level variables lose much of their explanatory power. The measures based on change since the last election are thus preferable.
} 


\section{An Instrumental Variables Model of Retrospective Voting}

Having identified instruments ( $\Delta$ County Income and $\Delta$ County Unemployment) for subjective perceptions of the national economy (Sociotropic Evaluation), we turn to the principle goal of the paper-testing the causal claim that subjective assessments affect presidential vote choice (i.e., the sociotropic economic voting hypothesis). Both prior work and the results presented in Table 1 suggest that subjective evaluations of the economy have a greater effect on vote choice in elections with an incumbent president on the ballot. To allow for this conditional effect, we need to instrument for two endogenous variables: Sociotropic Evaluation and Sociotropic Evaluation $\times$ Incumbent Candidate. ${ }^{15}$ We therefore include $\Delta$ County Income, $\Delta$ County Unemployment, $\Delta$ County Income $\times$ Incumbent Candidate and $\Delta$ County Unemployment $\times$ Incumbent Candidate as instruments for Sociotropic Evaluation and its interaction with Incumbent Candidate. ${ }^{16}$

There are two first stage models, one for each of the endogenous variables. All the "excluded" instruments and all the control variables needed for the second stage models are included as explanatory variables in both first stage models. The predicted values for these two endogenous variables are then substituted into the main equation and included along with the same set of control variables. The IV model is estimated with two-stage least squares instead of IV probit since the "IV-2SLS method is typically preferred even in cases in which the dependent variable is dichotomous" (Miguel, Satyanath, and Sergenti 2004, 738). The binary second stage model of

${ }^{15}$ Party ID is not as obviously exogenous as the other independent variables. However, theory and a good deal of evidence suggest that partisanship is stable and a part of a voter's social identity (e.g., Campbell, et al. 1960, Green, Palmquist, and Schickler 2002).

${ }^{16}$ This is the typical approach for incorporating interaction terms involving endogenous variables in an IV model (see Gabel and Scheve 2007; Hansford and Gomez 2010). 
whether the respondent states they will vote for the incumbent president/candidate from the president's party is thus a linear probability model.

To account for any election-specific influences on both subjective assessments of the economy and vote choice, we include election fixed effects in both stages of the model. These fixed effects absorb, for example, the effect of the actual state of the national economy and how it is discussed by the campaigns (Vavreck 2009) or the media (Hetherington 1996). We estimate robust standard errors that allow non-independent residuals within counties for each specific election. Model 3.1 in Table 3 presents these IV results. For the sake of comparison, the second column of this table presents the traditional OLS results obtained when Sociotropic Evaluation is assumed to be exogenous.

\section{[Table 3 Here]}

The IV estimate for Sociotropic Evaluation is positive and statistically significant, which leads to the same inference as the results obtained when this variable is treated as exogenous. It thus appears that when there is not an incumbent president seeking reelection voters take into account their evaluations of the state of the economy when deciding whether to vote for the candidate of the president's party. The better the voter's subjective assessment of the economy, the more likely s/he is to vote for the candidate of the president's party. This specific result is entirely consistent with the sociotropic economic voting hypothesis.

The truly striking difference between the IV results and those in which Sociotropic Evaluation is assumed to be exogenous is that the estimate for Sociotropic Evaluation $\times$ Incumbent Candidate is negative and statistically significant in the IV model, while it is positive and significant in the OLS model. The IV model's negative estimate for this interaction term reveals that the positive effect of Sociotropic Evaluation on vote choice goes away (turns negative, actually, though not in a statistically significant sense) when there is an incumbent president seeking reelection. This result, which proves 
to be quite robust, is sure to surprise most scholars of economic voting — as it did us. Simply put, variation in subjective evaluations of the state of the economy does not influence voters when the current president is on the ballot. This stands in sharp contrast to traditional models, which find that sociotropic voting is at its strongest when the incumbent seeks reelection.

What explains this major discrepancy in results across these models? The most likely culprit is the endogenous nature of self-reported assessments of the economy. ${ }^{17}$ When an incumbent is on the ballot, voters' assessments of the national economy appear to be particularly conflated with their support for the president. As noted earlier, cognitive dissonance provides one logical reason for this conflation. Supporters of the current president are likely to maintain economic assessments that cast the president's administration in a positive light, thus allowing these individuals to rationalize their support. Opponents of the president are likely to maintain economic assessments that do not cast the current administration in a positive light, thus justifying their opposition to the incumbent. As a result, these assessments correlate strongly with vote choice, but they do not appear to actually cause vote choice when there is an incumbent presidential candidate. ${ }^{18}$ Traditional models of economic voting, which do not account for endogeneity, cannot make this distinction. ${ }^{19}$

\footnotetext{
${ }^{17} \mathrm{~A}$ Wu-Hausman test indicates we cannot reject the null hypothesis that Sociotropic Evaluation is exogenous, but we can reject the null hypothesis that Sociotropic Evaluation $\times$ Incumbent Candidate is exogenous $(p=.026)$.

${ }^{18}$ Another possibility is that the effect of local economic conditions on economic perceptions is greatest when there is not a reelection-seeking incumbent who might be able to alter the frame by which their performance is evaluated. Or, a reelection-seeking president may distribute federal money in a way that affects local economic conditions and correlates with the aggregate partisan tendency of the locality. There is no evidence for either of these patterns in our data, though.
} 


\subsection{Weak Instruments?}

Given that the results we obtain with our IV model, in part, run counter to the sociotropic economic voting hypothesis and supporting studies, further consideration of the robustness of our results is warranted. We have demonstrated that county-level economic conditions predict subjective evaluations of the national economy, but as with any IV model we need to consider whether these instruments are "weak" and thus might lead to estimates that are nearly as biased as those produced by OLS. ${ }^{20}$ Stock and Yogo (2005) provide a test for whether instruments are weak and this test reveals that the bias in our IV estimates is less than 10 percent of the bias in the OLS estimates. This result suggests that our instruments are not weak. Nonetheless, we also use an alternative estimator (Fuller's limited information maximum likelihood) for our IV model (Model 3.1) that behaves well in the presence of weak instruments and obtain results that are very similar to those presented in Table 3. The Online Appendix provides the details of this analysis.

When $\Delta$ County Income and $\Delta$ County Unemployment are interacted with Incumbent Candidate in the model predicting Sociotropic Evaluation, the estimates for these interaction terms are not statistically significant (see the Online Appendix). The effect of county-level economic conditions on perceptions of the national economy is not conditioned by a reelection-seeking incumbent.

${ }^{19}$ To further probe the robustness of our IV results, we estimate a single-stage reduced-form model and present the results in the Online Appendix (see Table A7). $\Delta$ County Income is included directly in the main model predicting vote for the incumbent candidate/party. This reduced-form model does not require the sociotropic question, which allows us to add two more presidential elections to our data; 1972 and 1976. The results of this model are fully consistent with those of our IV model.

${ }^{20}$ See Murray (2006) for a highly readable summary of the issue of weak instruments. 


\subsection{The Exclusion Restriction and Instrument Validity}

We have made the case for the usefulness of county-level economic conditions as an instrument for individual-level sociotropic evaluations and have demonstrated that these conditions predict such evaluations. We also argue that objective local economic conditions must be exogenous to vote choice. Yet one issue we have not considered is whether the county-level economic variables meet the exclusion restriction (e.g., Angrist, Imbens, and Rubin 1996). For an IV model to estimate the causal effect of a potentially endogenous variable on a dependent variable, the instruments for the endogenous variable must have "no direct effect on the outcome" (Sovey and Green 2011, 198, emphasis added). Put differently, this restriction posits that "an instrument operates through a single known causal channel" (Angrist and Pischke 2009, 153) and this channel involves the endogenous regressor.

In our IV model, the exclusion restriction would be violated if $\Delta$ County Income and $\Delta$ County Unemployment directly influenced voting for the incumbent candidate/party, independent of any effect these variables exert on vote choice through determining Sociotropic Evaluation. We need to emphasize it is perfectly consistent with our approach for $\Delta$ County Income and $\Delta$ County Unemployment to have an indirect influence on vote choice whereby these two variables predict Sociotropic Evaluation, which might then affect vote choice. ${ }^{21}$

Theoretically, two potential concerns regarding the exclusion restriction in our IV model warrant discussion. First, it is possible that county-level economic conditions cause subjective pocketbook evaluations, which in turn cause votes. This seems an unlikely causal pathway given the

21 In our Online Appendix we present a reduced-form model in which $\Delta$ County Income is included as an exogenous "proxy" for Sociotropic Evaluation in a reduced-form, single stage model of vote choice. 
evidence that pocketbook evaluations are not a consistent correlate of vote choice (see Lewis-Beck and Stegmaier 2000,194). Indeed, previous attempts to exogenize economic perceptions have also dismissed this causal path (e.g., Lewis-Beck, Nadeau, and Elias 2008, 90). Second, it is possible that county-level conditions are consciously and independently incorporated into a voter's calculus and thus directly influence vote choice. There is little evidence of meaningful state- or county-level retrospection in presidential elections and the limited evidence that exists does not demonstrate that votes are directly influenced by local conditions (e.g., Holbrook 1991; Eisenberg and Ketcham 2004). It seems more plausible that local conditions are observed by voters and used to help form their evaluation of the national economy (our assumption). It is less plausible that voters keep distinct, informed evaluations of the local and national economies and consider each separately when casting a vote. Importantly, we should note that either of these potential violations of the exclusion restriction ought to bias our results towards finding sociotropic voting. We thus feel confident in the null result we obtain when there is a reelection-seeking incumbent.

Typically, researchers rely on one instrument per endogenous variable, in which case the assumption that instruments are independent of the error term remains a purely theoretical debate. Fortunately, we have more instruments than we do endogenous variables. This allows us to conduct an over-identification test which, while not definitive, helps assess the validity of our instruments. The Sargan-Hansen test is based on a regression of the instruments on the residuals of the main or second stage model in which the null hypothesis is that the instruments are uncorrelated with the error term, which can then be viewed as an indication that the instruments are valid. For our model (Model 3.1), the test statistic leads us to fail to reject this null $(p=.108)$, thus supporting the validity of our instruments.

To the extent that a $p$-value of slightly over .1 could be viewed as a little close for comfort, additional analyses reveal that instrument validity is most clearly established in the elections for 
which there is an incumbent president on the ballot. For this subset of elections, the Sargan-Hansen test leads us to fail to reject the null that are instruments are uncorrelated with the residuals in the second stage model $(p=.391)$ and thus suggests that the instruments are valid. It is for this subset of elections that our IV results could be viewed as most controversial, since these are the elections for which scholars argue retrospective voting should be prominent but for which our statistical results provide no evidence. To further demonstrate the robustness of our results, we re-estimate our IV model using only the elections in which a president is on the ballot and present these results as Model 4.1 in Table 4. In this model, we do not interact Sociotropic Evaluation or the instruments with Incumbent Candidate since only elections with incumbent candidates are included. For the purposes of comparison, we also present this model as estimated by OLS with the assumption that Sociotropic Evaluation is exogenous (Model 4.2).

\section{[Table 4 Here]}

The IV estimate for Sociotropic Evaluation is neither statistically significant nor in the direction predicted by the retrospective voting hypothesis. Again, there is no evidence that subjective individual-level assessments of the economy affect vote choice when there is an incumbent president on the ballot. Without accounting for endogeneity, scholars are likely to draw the wrong causal inference. The traditional OLS result shows that there is a positive correlation between reported assessments of the economy and the respondent's vote, but there does not appear to be causal relationship in this subset of elections.

Putting all these results together, when the endogeneity of self-reported economic assessments is ignored we see across-the-board support for the retrospective voting hypothesis and find that these assessments have the biggest effect in elections featuring the president as a candidate. This evidence for retrospective voting is replicated when exogenous influences on these subjective evaluations is leveraged to better estimate the presence of a causal relationship, but only for elections in 
which there is not an incumbent on the ballot. When an incumbent president is seeking reelection, we find no evidence of a causal relationship between voter assessments of the economy and the decision to vote for the president.

Though more general in our treatment of incumbency, our result is consistent with Evans and Pickup's (2010) conclusion that economic perceptions had no influence in the 2004 presidential election, as this was, recall, an election with incumbent President Bush seeking reelection. Again, our work differs from that of Evans and Pickup, who test the effects of changes to an individual's evaluations of the economy, while we have focused on the effects of differences between individuals. This result is also consistent with what Gomez and Hansford (N.d.) find in their study of voter turnout in presidential elections, as they conclude that there is only a retrospective component to turnout decisions when there is not a reelection-seeking incumbent.

\section{Conclusion}

Edward R. Tufte $(1978,65)$ proclaimed "[w] hen you think economics, think elections; when you think elections, think economics." Though Tufte may not have considered it when making this claim, this entanglement between economics and elections illustrates the possibility of endogeneity when individuals simultaneously construct their evaluations of the economy and their vote choices. For example, voters may tend to overstate the soundness of the national economy when they intend to vote for the president (president's party), while understating it when the opposition governs. If this is indeed the case, then traditional tests of the retrospective sociotropic voting hypothesis may not provide a valid test of this important causal claim.

We argue that objective local economic circumstances predict individuals' perceptions of the national economy, are exogenous to vote choice, and serve as a useful instrument for retrospective sociotropic evaluations. Our study uses an IV model of cross-sectional data to identify the causal effect of differences across individuals' retrospective evaluations on decisions to vote for the 
incumbent president or his party's nominee. These models support the existence of retrospective voting when the president is not seeking reelection but fail to provide any evidence for sociotropic evaluations influencing whether people will vote for an incumbent president. Remarkably, it is in the latter type of election that the literature suggests retrospective voting should be most prominent. Why do our results support the presence of retrospective voting when there is not an incumbent candidate? This pattern of results suggests that sociotropic evaluations are less endogenous when the president is not running for reelection. Stated differently, self-reported evaluations of the economy may be less contaminated with unmeasured attitudes about the president when he is not one of the candidates. This near-exogeneity leads traditional modeling approaches to find a connection between sociotropic evaluations and vote choice that is more modest in magnitude than when there is an incumbent candidate. Likewise, this near-exogeneity would explain why our IV approach confirms the presence of a causal relationship.

Why might individual-level evaluations of the economy correlate with but not actually cause vote choice when there is an incumbent candidate? The likely first part of the answer here is that sociotropic evaluations are particularly endogenous when the president is one of the candidates. In this situation, voters project their overall affinity for the president onto their evaluations of the economy. Thus, the strong correlation between sociotropic evaluations and vote choice. This overall evaluation of the president may then dominate the vote calculus, leaving little room for any exogenous component of sociotropic evaluations to matter. Put differently, voters may have a more hardened, relatively information-saturated view of a president, but a more malleable impression of a candidate from the president's party. In the absence of an incumbent on the ballot, genuine sociotropic evaluation may be an information shortcut for voters. 


\section{Acknowledgments}

Earlier versions of this paper were presented at annual meetings of the American Political Science Association, September 1-4, 2011, Seattle, WA and Southern Political Science Association, January 6-8, 2011, New Orleans, LA. The authors thank Andy Healy, Heather Ondercin, and the participants in a CNISS seminar at Washington University in St. Louis for their constructive

comments during the writing of this paper. Rosmery Cruz and Jim Martin of Florida State University provided research assistance. This research was supported by a UC Merced Academic Senate Faculty Research Grant. Errors are attributable to the authors alone. 


\section{References}

Anderson, Christopher J., Silvia M. Mendes, and Yuliya V. Tverdova. 2004. "Endogenous Economic Voting: Evidence from the 1997 British Election.” Electoral Studies 23(4):683-708.

Angrist, Joshua D., Guido W. Imbens, and Donald B. Rubin. 1996. "Identification of Causal Effects Using Instrumental Variables." Journal of the American Statistical Association 91(2):444-455.

Angrist, Joshua D., and Jorn-Steffen Pischke. 2009. Mostly Harmless Econometrics: An Empiricist's Companion. Princeton, NJ: Princeton University Press.

Bartels, Larry M. 2002. "Beyond the Running Tally: Partisan Bias in Political Perceptions.” Political Behavior 24(2):117-150.

Books, John W., and Charles L. Prysby. 1991. Political Behavior and the Local Context. New York: Praeger.

Campbell, Angus, Philip E. Converse, Warren E. Miller, and Donald E. Stokes. 1960. The American Voter. New York: John Wiley \& Sons, Inc.

Duch, Raymond M., Harvey D. Palmer, and Christopher J. Anderson. 2000. "Heterogeneity in Perceptions of National Economic Conditions." American Journal of Political Science 44(4):635652.

Duch, Raymond M., and Randolph T. Stevenson. 2008. The Economic Vote: How Political and Economic Institutions Condition Election Results. New York: Cambridge University Press.

Dunning, Thad. 2008. "Model Specification in Instrumental-Variables Regression.” Political Analysis 16 (Summer): 290-302.

Eisenberg, Daniel, and Jonathan Ketcham. 2004. "Economic Voting in U.S. Presidential Elections: Who Blames Whom for What.” B.E. Journal of Economic Analysis \& Policy 4(1):Article 19. 
Erikson, Robert S. 2004. "Macro vs. Micro-Level Perspectives on Economic Voting: Is the Micro Level Evidence Endogenously-Induced?” Paper presented at the 2004 Political Methodology Meeting, Stanford University.

Evans, Geoffrey, and Robert Anderson. 2006. "The Political Conditioning of Economic Perceptions." Journal of Politics 68(1):194-207.

Evans, Geoffrey, and Mark Pickup. 2010. "Reversing the Causal Arrow: The Political Conditioning of Economic Perceptions in the 2000-2004 U.S. Presidential Election Cycle.” Journal of Politics 72(4):1236-1251.

Fearon, James D. 1999. "Electoral Accountability and the Control of Politicians: Selecting Good Types versus Sanctioning Poor Performance.” In Bernard Manin, Adam Przeworski, and Susan Stokes, eds. Democracy, Accountability, and Representation. New York: Cambridge University Press.

Fiorina, Morris P. 1981. Retrospective Voting in American National Elections. New Haven, CT: Yale University Press.

Fraile, Marta, and Michael S. Lewis-Beck. 2010. "Economic Voting in Spain: A 2000 Panel Test." Electoral Studies 29(2):210-220.

Gabel, Matthew, and Kenneth Scheve. 2007. "Estimating the Effect of Elite Communications on Public Opinion Using Instrumental Variables.” American Journal of Political Science 51(4):10131028.

Gaines, Brian J., James H. Kuklinski, Paul J. Quirk, Buddy Peyton, and Jay Verkuilen. 2007. “Same Facts, Different Interpretations: Partisan Motivation and Opinion on Iraq." Journal of Politics 69(4):957-974.

Gomez, Brad T., and Thomas G. Hansford. N.d. "Economic Retrospection and Voter Turnout." Political Behavior, forthcoming (published online May 30, 2014). 
Gomez, Brad T., and J. Matthew Wilson. 2001. "Political Sophistication and Economic Voting in the American Electorate: A Theory of Heterogeneous Attribution.” American Journal of Political Science 45(4):899-914.

Gomez, Brad T., and J. Matthew Wilson. 2003. "Causal Attribution and Economic Voting in American Congressional Elections.” Political Research Quarterly 56(3):271-282.

Gomez, Brad T., and J. Matthew Wilson. 2006. "Cognitive Heterogeneity and Economic Voting: A Comparative Analysis of Four Democratic Electorates." American Journal of Political Science 50(1):127-145.

Green, Donald, Bradley Palmquist, and Eric Schickler. 2002. Partisan Hearts \& Minds: Political Parties and the Social Identities of Voters. New Haven: Yale University Press.

Hansford, Thomas G., and Brad T. Gomez. 2010. "Estimating the Electoral Effects of Voter Turnout." American Political Science Review 104(2):268-288.

Hetherington, Marc J. 1996. “The Media’s Role in Forming Voters' National Economic Evaluations in 1992." American Journal of Political Science 40(2):372-395.

Holbrook, Thomas M. 1991. "Presidential Elections in Space and Time." American Journal of Political Science 35(1):91-109.

Jacobson, Gary C. 1989. "Strategic Politicians and the Dynamics of U.S. House Elections, 19461986." American Political Science Review 83(3):773-793.

Key, V. O., Jr. 1966. The Responsible Electorate: Rationality in Presidential Voting, 1936-1960. Cambridge, MA: Belknap Press of Harvard University Press.

Kiewiet, D. Roderick. 1983. Macroeconomics and Micropolitics: The Electoral Effects of Economic Issues. Chicago: University of Chicago Press.

Kinder, Donald R., Gordon S. Adams, and Paul W. Gronke. 1989. "Economics and Politics in the 1984 American Presidential Elections.” American Journal of Political Science 33(2):491-515. 
Kinder, Donald R., and D. Roderick Kiewiet. 1981. "Sociotropic Politics: The American Case." British Journal of Political Science 11(2):129-161.

Kramer, Gerald H. 1971. "Short-Term Fluctuations in U.S. Voting Behavior.” American Political Science Review 65(1):131-143.

Kramer, Gerald H. 1983. “The Ecological Fallacy Revisited: Aggregate versus Individual Level Findings on Economics and Elections and Sociotropic Voting." American Political Science Review 77(1):92-111.

Lewis-Beck, Michael S. 1988. Economics and Elections: The Major Western Democracies. Ann Arbor: University of Michigan Press.

Lewis-Beck, Michael S., Richard Nadeau, and Angelo Elias. 2008. "Economics, Party, and the Vote: Causality Issues and Panel Data." American Journal of Political Science 52(1):84-95.

Lewis-Beck, Michael S., and Martin Paldam. 2000. “Economic Voting: An Introduction.” Electoral Studies 19(2):113-121.

Lewis-Beck, Michael S., and Mary Stegmaier. 2000. "Economic Determinants of Electoral Outcomes." Annual Review of Political Science 3(2):183-219.

Lewis-Beck, Michael S., Rune Stubager, and Richard Nadeau. 2013. “The Kramer Problem: MicroMacro Resolution with a Danish Pool.” Electoral Studies 32:500-505.

Lockerbie, Brad. 1992. "Prospective Voting in Presidential Elections, 1956-1988." American Politics Quarterly 20(3):308-325.

Markus, Gregory B. 1988. “The Impact of Personal and National Economic Conditions on the Presidential Vote: A Pooled Cross-Sectional Analysis.” American Journal of Political Science 32(1):137-154.

Miguel, Edward, Shanker Satyanath, and Ernest Sergenti. 2004. "Economic Shocks and Civil Conflict: An Instrumental Variables Approach.” Journal of Political Economy 112(3):725-753. 
Miller, Arther H., and Martin P. Wattenberg. 1985. “Throwing the Rascals Out: Policy and Performance Evaluations of Presidential Candidates, 1952-1980.” American Political Science Review 79(2):359-72.

Murray, Michael P. 2006. "Avoiding Invalid Instruments and Coping with Weak Instruments." Journal of Economic Perspectives 20(4):111-132.

Nadeau, Richard, and Michael S. Lewis-Beck. 2001. "National Economic Voting in U.S. Presidential Elections." Journal of Politics 63(1):159-81.

Nadeau, Richard, Michael S. Lewis-Beck, and Eric Belanger. 2013. "Economics and Elections Revisited." Comparative Political Studies 46(5):551-573.

Nisbett, Richard, and Lee Ross. 1980. Human Inference: Strategies and Shortcomings of Social Judgment. Englewood Cliffs, NJ: Prentice Hall.

Norpoth, Helmut. 2002. “On a Short Leash: Term Limits and the Economic Voter.” in Han Dorussen and Michael Taylor, eds. Economic Voting. London: Routledge.

Pacek, Alexander C., and Benjamin Radcliff. 1995. "Economic Voting and the Welfare State: A Cross-National Analysis." Journal of Politics 57(1):44-61.

Parker-Stephen, Evan. 2013. “Clarity of Responsibility and Economic Evaluations.” Electoral Studies 32:506-511.

Pickup, Mark, and Geoffrey Evans. 2013. “Addressing the Endogeneity of Economic Evaluations in Models of Political Change." Public Opinion Quarterly 77(3):735-754.

Powell, G. Bingham, and Guy D. Whitten. 1993. “A Cross-National Analysis of Economic Voting: Taking Account of the Political Context." American Journal of Political Science 37(2):391-414. Smith, Alastair. 2003. "Election Timing in Majoritarian Parliaments." British Journal of Political Science 33(3):397-418. 
Sovey, Allison J, and Donald P. Green. 2011. "Instrumental Variables Estimation in Political Science: A Readers' Guide.” American Journal of Political Science 55(1):188-200.

Staiger, Douglas, and James H. Stock. 1997. "Instrumental Variables Regression with Weak Instruments.” Econometrica 65(2):557-586.

Stevenson, Randolph T., and Raymond Duch. 2013. "The Meaning and Use of Subjective Perceptions in Studies of Economic Voting.” Electoral Studies 32(2):305-320.

Stock, James H., and Motohiro Yogo. 2005. “Testing for Weak Instruments in IV Regression.” In Identification and Inferences for Econometric Models, Donald W. K. Andrews and James H. Stock, Eds. Cambridge University Press.

Taber, Charles S., and Milton Lodge. 2006. "Motivated Skepticism in the Evaluation of Political Beliefs." American Journal of Political Science 50(2):755-769.

Tilley, James, John Garry, and Tessa Bold. 2008. "Perceptions and Reality: Economic Voting at the 2004 European Parliament Elections.” European Journal of Political Research 47(3):665-686.

Tufte, Edward R. 1978. Political Control of the Economy. Princeton, NJ: Princeton University Press. Van der Brug, Wouter, Cees van der Eijk, and Mark Franklin. 2007. The Economy and The Vote. New York: Cambridge University Press.

Vavreck, Lynn. 2009. The Message Matters: The Economy and Presidential Campaigns. Princeton, NJ: Princeton University Press.

Weatherford, M. Stephen. 1983. "Evaluating Economic Policy: A Contextual Model for the Opinion Formation Process." Journal of Politics 45(4):866-888.

Wlezien, Christopher, Mark Franklin, and Daniel Twiggs. 1997. "Economic Perceptions and Vote Choice: Disentangling the Endogeneity.” Political Behavior 19(1):7-17. 
TABLE 1. Effect of subjective sociotropic evaluations on vote for incumbent president/party, 1980 to 2008 .

Independent Variable

Sociotropic Evaluation

Sociotropic Evaluation $\times$ Incumbent Candidate
Model 1.1

$.191 *$

.153*

(.042)

Yes

Yes

$\mathrm{N}$

9,568

$* p \leq .05$ (two-tailed test). Cell entries are probit estimates (with robust standard errors clustered on election year). Controls include Party ID, Party ID $\times$ Democratic Incumbent $(D I)$, Personal Income, Personal Income $\times D I$, Education, Education $\times D I$, Unemployed, Unemployed $\times D I$, Black, Black $\times$ DI, Female, Female $\times D I$, Age, Age $\times$ DI. The constitutive terms, Democratic Incumbent $(D I)$ and Incumbent Candidate, are omitted from the model because they are subsumed by the election effects captured by the inclusion of fixed effects. See the Online Appendix (Table A1) for full results. 
TABLE 2. Effect of local objective conditions on sociotropic evaluations.

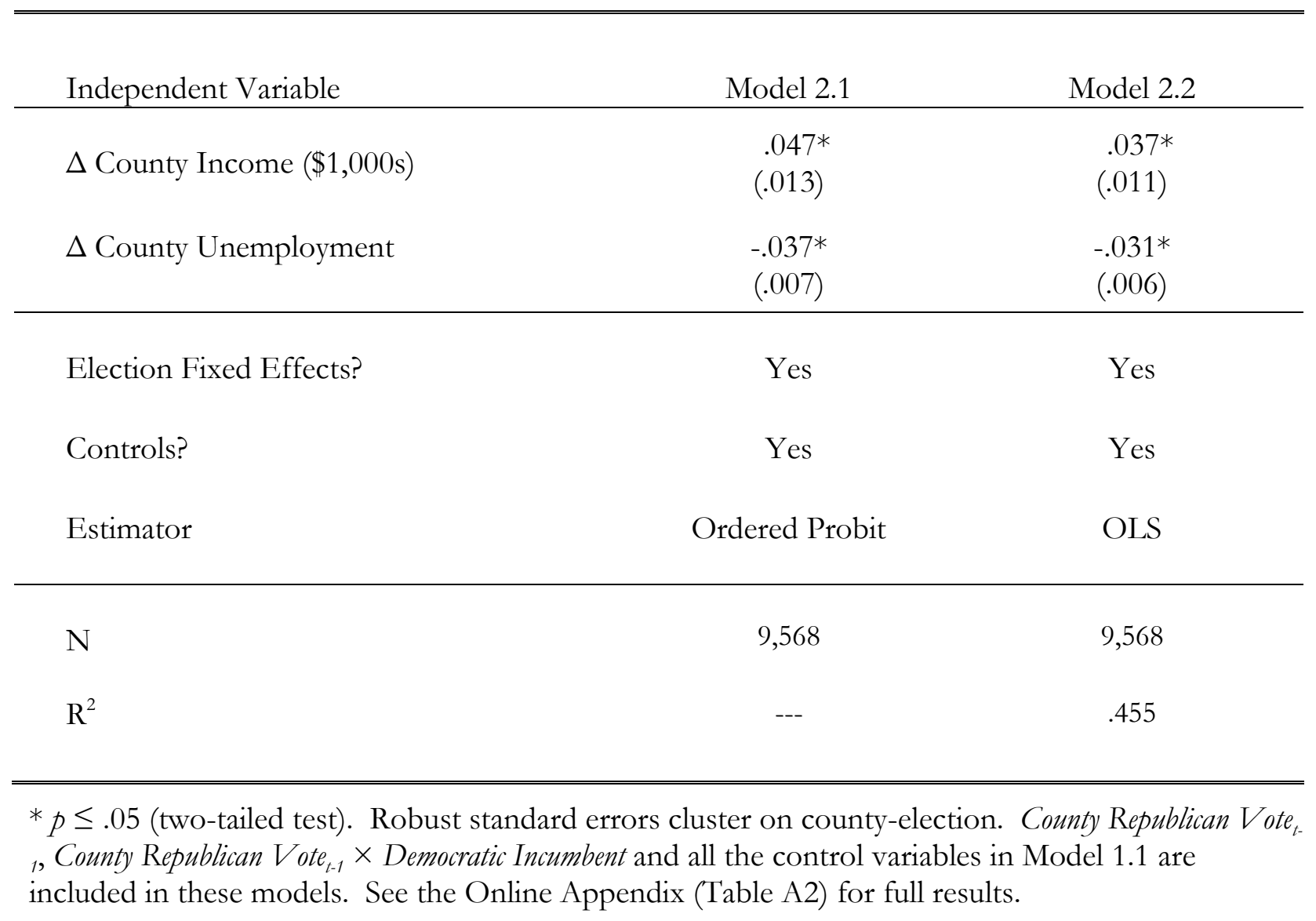


TABLE 3. Instrumental variables (IV) model of the effect of sociotropic evaluations on vote for incumbent president/party.

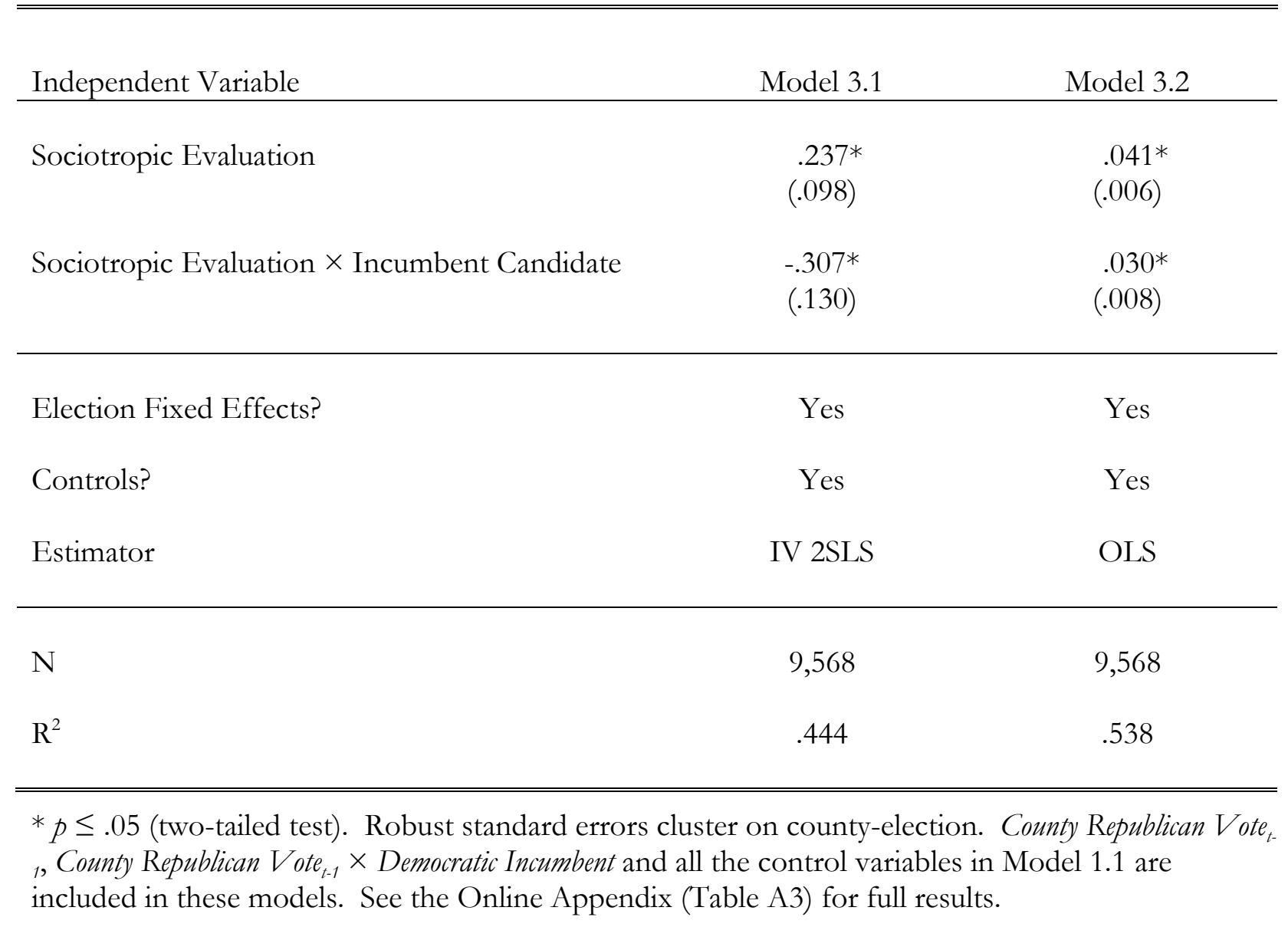


TABLE 4. Instrumental variables (IV) model of the effect of sociotropic evaluations on vote for incumbent president.

\begin{tabular}{lcc}
\hline \hline & & \\
Independent Variable & Model 4.1 & Model 4.2 \\
\hline Sociotropic Evaluation & -.027 & $.080^{*}$ \\
& $(.082)$ & $(.006)$ \\
\hline Election Fixed Effects? & Yes & Yes \\
Controls? & Yes & Yes \\
Estimator & IV 2SLS & OLS \\
\hline $\mathrm{N}$ & & 5,781 \\
$\mathrm{R}^{2}$ & 5,781 & .514 \\
\hline \hline
\end{tabular}

$* p \leq .05$ (two-tailed test). Robust standard errors cluster on county-election. Only elections with an incumbent president on the ballot are included. County Republican Vote ${ }_{t-1}$, County Republican Vote ${ }_{t-1}$ $\times$ Democratic Incumbent and all the control variables in Model 1.1 are included in these models. See the Online Appendix (Table A4) for full results. 


\section{Reevaluating the Sociotropic Economic Voting Hypothesis *** On-Line Appendix ***}

Full results of models presented in Table 1 of the manuscript 2

Full results of models presented in Table 2 of the manuscript 3

Full results of models presented in Table 3 of the manuscript 4

Full results of models presented in Table 4 of the manuscript 5

Estimating our IV model with Fuller's LIML approach 6-7

Testing whether Incumbent Candidate conditions the effect of local conditions

Reduced form model, 1972 to $2008 \quad 10-11$ 
TABLE A1(Full Results). Effect of subjective sociotropic evaluations on vote for incumbent president/party, 1980 to 2008.

\begin{tabular}{|c|c|}
\hline Independent Variable & Model 1.1 \\
\hline Sociotropic Evaluation & $\begin{array}{l}.191 * \\
(.027)\end{array}$ \\
\hline Sociotropic Evaluation $\times$ IC & $\begin{array}{c}.153 * \\
(.042)\end{array}$ \\
\hline Party ID & $\begin{array}{c}.507^{*} \\
(.024)\end{array}$ \\
\hline Party ID × DI & $\begin{array}{c}-1.03^{*} \\
(.049)\end{array}$ \\
\hline Personal Income & $\begin{array}{c}.076^{*} \\
(.029)\end{array}$ \\
\hline Personal Income $\times$ DI & $\begin{array}{c}-.071^{*} \\
(.031)\end{array}$ \\
\hline Education & $\begin{array}{c}-.035^{*} \\
(.016)\end{array}$ \\
\hline Education $\times$ DI & $\begin{array}{c}.025 \\
(.040)\end{array}$ \\
\hline Unemployed & $\begin{array}{c}-.249 * \\
(.088)\end{array}$ \\
\hline Unemployed $\times$ DI & $\begin{array}{c}.478^{*} \\
(.143)\end{array}$ \\
\hline Black & $\begin{array}{l}-.842^{*} \\
(.209)\end{array}$ \\
\hline Black $\times$ DI & $\begin{array}{c}1.91 * \\
(.298)\end{array}$ \\
\hline Female & $\begin{array}{c}.103 \\
(.067)\end{array}$ \\
\hline Female $\times$ DI & $\begin{array}{l}.135 \\
(.071)\end{array}$ \\
\hline Age & $\begin{array}{c}.005^{*} \\
(.002)\end{array}$ \\
\hline Age $\times$ DI & $\begin{array}{l}-.003 \\
(.003)\end{array}$ \\
\hline Election Fixed Effects? & Yes \\
\hline $\mathrm{N}$ & 9,568 \\
\hline
\end{tabular}

$* p \leq .05$ (two-tailed test). Cell entries are probit coefficient estimates (with robust standard errors allowing for clustering on election year). The constitutive terms, Democratic Incumbent (DI) and Incumbent Candidate, are omitted from the model because they are subsumed by the election effects captured by the inclusion of fixed effects. 
TABLE A2 (Full Results). Effect of local objective conditions on sociotropic evaluations.

Independent Variable

$\Delta$ County Income $(\$ 1,000$ s $)$

$\Delta$ County Unemployment

Party ID

Party ID $\times$ Democratic Incumbent (DI)

Personal Income

Personal Income $\times$ DI

Education

Education $\times$ DI

Unemployed

Unemployed $\times$ DI

Black

Black $\times$ DI

Female

Female $\times$ DI

Age

Age $\times$ DI

County Republican Vote $_{t-1}$

County Republican Vote $_{t-1} \times$ DI
Model 2.1

$\begin{array}{cc}.047^{*} & .037^{*} \\ (.013) & (.011) \\ . .037^{*} & -.031^{*} \\ (.007) & (.006) \\ .17)^{*} & .144^{*} \\ (.007) & (.006) \\ -.311^{*} & -.254^{*} \\ (.012) & (.010) \\ .014 & .015 \\ (.016) & (.012) \\ -.025 & -.022 \\ (.028) & (.023) \\ .012 & .011 \\ (.009) & (.007) \\ .004 & .003 \\ (.016) & (.013) \\ -.100 & -.073 \\ (.061) & (.044) \\ .118 & .089 \\ (.120) & (.096) \\ -.044 & -.026 \\ (.063) & (.046) \\ -.029 & -.039 \\ (.100) & (.080) \\ -.259^{*} & -.202^{*} \\ (.027) & (.021) \\ .193 * & .152^{*} \\ (.049) & (.041) \\ -.002^{*} & -.002^{*} \\ (.001) & (.001) \\ .006^{*} & .005^{*} \\ (.002) & (.001) \\ .002 & .001 \\ (.001) & (.001) \\ -.004 & -.003 \\ (.003) & (.002) \\ . . & \\ & \end{array}$

\begin{tabular}{lcc}
\hline Estimator & Ordered Probit & OLS \\
\hline $\mathrm{N}$ & 9,568 & 9,568 \\
Wald Test & $3,214^{*}$ & --- \\
F-Test & --- & $246^{*}$ \\
$\mathrm{R}^{2}$ & --- & .455 \\
\hline
\end{tabular}

$* p \leq .05$ (two-tailed test). Cell entries are coefficient estimates (with robust standard errors allowing for clustering on county-election). Democratic Incumbent is not included in these models as it is subsumed by the election effects. 
TABLE A3 (Full Results). Instrumental variables (IV) model of the effect of sociotropic evaluations on vote for incumbent president/party.

\begin{tabular}{|c|c|c|}
\hline Independent Variable & Model 3.1 & Model 3.2 \\
\hline Sociotropic Evaluation & $\begin{array}{c}.238^{*} \\
(.098)\end{array}$ & $\begin{array}{c}.041 * \\
(.006)\end{array}$ \\
\hline Sociotropic Eval. $\times$ Incumbent Candidate & $\begin{array}{c}-.307^{*} \\
(.130)\end{array}$ & $\begin{array}{c}.030^{*} \\
(.008)\end{array}$ \\
\hline Party ID & $\begin{array}{c}.144^{*} \\
(.010)\end{array}$ & $\begin{array}{c}.138^{*} \\
(.003)\end{array}$ \\
\hline Party ID $\times$ Democratic Incumbent $(\mathrm{DI})$ & $\begin{array}{c}-.288^{*} \\
(.016)\end{array}$ & $\begin{array}{c}-.280^{*} \\
(.004)\end{array}$ \\
\hline Personal Income & $\begin{array}{c}.023^{*} \\
(.006)\end{array}$ & $\begin{array}{c}.015^{*} \\
(.005)\end{array}$ \\
\hline Personal Income $\times$ DI & $\begin{array}{c}-.022^{*} \\
(.010)\end{array}$ & $\begin{array}{l}-.012 \\
(.008)\end{array}$ \\
\hline Education & $\begin{array}{l}-.003 \\
(.004)\end{array}$ & $\begin{array}{c}-.007 * \\
(.003)\end{array}$ \\
\hline Education $\times$ DI & $\begin{array}{c}.002 \\
(.006)\end{array}$ & $\begin{array}{l}.005 \\
(.005)\end{array}$ \\
\hline Unemployed & $\begin{array}{c}-.059 * \\
(.019)\end{array}$ & $\begin{array}{c}-.045^{*} \\
(.016)\end{array}$ \\
\hline Unemployed $\times$ DI & $\begin{array}{c}.082^{*} \\
(.037)\end{array}$ & $\begin{array}{c}.084 * \\
(.032)\end{array}$ \\
\hline Black & $\begin{array}{c}-.123^{*} \\
(.016)\end{array}$ & $\begin{array}{c}-.106^{*} \\
(.013)\end{array}$ \\
\hline Black $\times$ DI & $\begin{array}{c}.291 * \\
(.026)\end{array}$ & $\begin{array}{c}.295^{*} \\
(.023)\end{array}$ \\
\hline Female & $\begin{array}{c}.016 \\
(.016)\end{array}$ & $\begin{array}{c}.020^{*} \\
(.009)\end{array}$ \\
\hline Female $\times$ DI & $\begin{array}{c}.019 \\
(.020)\end{array}$ & $\begin{array}{c}.033^{*} \\
(.016)\end{array}$ \\
\hline Age & $\begin{array}{c}.001 * \\
(.000)\end{array}$ & $\begin{array}{c}.001 * \\
(.000)\end{array}$ \\
\hline Age $\times$ DI & $\begin{array}{l}-.001 \\
(.001)\end{array}$ & $\begin{array}{l}-.001 \\
(.000)\end{array}$ \\
\hline County Republican Vote $_{t-1}$ & $\begin{array}{c}.002^{*} \\
(.000)\end{array}$ & $\begin{array}{c}.002^{*} \\
(.000)\end{array}$ \\
\hline County Republican Vote $_{t-1} \times$ DI & $\begin{array}{c}-.003^{*} \\
(.001)\end{array}$ & $\begin{array}{c}-.004 * \\
(.001)\end{array}$ \\
\hline Estimator & IV 2SLS & OLS \\
\hline $\mathrm{N}$ & 9,568 & 9,568 \\
\hline F-Test & $425^{*}$ & $659 *$ \\
\hline $\mathrm{R}^{2}$ & .444 & .538 \\
\hline
\end{tabular}

$* p \leq .05$ (two-tailed test). Cell entries are coefficient estimates (and robust standard errors clustering on county-election). Election fixed effects are included. Democratic Incumbent and Incumbent Candidate are not included in these models as they are subsumed by the election effects. 
TABLE A4 (Full Results). Instrumental variables (IV) model of the effect of sociotropic evaluations on vote for incumbent president.

\begin{tabular}{|c|c|c|}
\hline Independent Variable & Model 4.1 & Model 4.2 \\
\hline Sociotropic Evaluation & $\begin{array}{l}-.027 \\
(.082)\end{array}$ & $\begin{array}{c}.080^{*} \\
(.006)\end{array}$ \\
\hline Party ID & $\begin{array}{c}.151 * \\
(.015)\end{array}$ & $\begin{array}{c}.133 * \\
(.003)\end{array}$ \\
\hline Party ID $\times$ Democratic Incumbent $(\mathrm{DI})$ & $\begin{array}{c}-.293 * \\
(.023)\end{array}$ & $\begin{array}{c}-.263 * \\
(.005)\end{array}$ \\
\hline Personal Income & $\begin{array}{c}.014 \\
(.008)\end{array}$ & $\begin{array}{c}.009 \\
(.006)\end{array}$ \\
\hline Personal Income $\times$ DI & $\begin{array}{l}-.011 \\
(.012)\end{array}$ & $\begin{array}{l}-.004 \\
(.011)\end{array}$ \\
\hline Education & $\begin{array}{l}-.006 \\
(.005)\end{array}$ & $\begin{array}{c}-.009^{*} \\
(.005)\end{array}$ \\
\hline Education $\times$ DI & $\begin{array}{l}-.003 \\
(.007)\end{array}$ & $\begin{array}{l}-.002 \\
(.007)\end{array}$ \\
\hline Unemployed & $\begin{array}{c}-.073^{*} \\
(.029)\end{array}$ & $\begin{array}{c}-.053^{*} \\
(.022)\end{array}$ \\
\hline Unemployed $\times$ DI & $\begin{array}{c}.088^{*} \\
(.046)\end{array}$ & $\begin{array}{c}.075 \\
(.042)\end{array}$ \\
\hline Black & $\begin{array}{c}-.115^{*} \\
(.027)\end{array}$ & $\begin{array}{c}-.088^{*} \\
(.019)\end{array}$ \\
\hline Black $\times$ DI & $\begin{array}{l}.341 * \\
(.031)\end{array}$ & $\begin{array}{c}.331 * \\
(.030)\end{array}$ \\
\hline Female & $\begin{array}{c}.007 \\
(.023)\end{array}$ & $\begin{array}{c}.030^{*} \\
(.013)\end{array}$ \\
\hline Female $\times$ DI & $\begin{array}{c}.036 \\
(.022)\end{array}$ & $\begin{array}{c}.026 \\
(.020)\end{array}$ \\
\hline Age & $\begin{array}{c}.001 \\
(.000)\end{array}$ & $\begin{array}{l}.001 * \\
(.000)\end{array}$ \\
\hline Age $\times$ DI & $\begin{array}{c}.000 \\
(.001)\end{array}$ & $\begin{array}{l}-.000 \\
(.001)\end{array}$ \\
\hline County Republican Vote Vot $_{t}$ & $\begin{array}{c}.001 \\
(.001)\end{array}$ & $\begin{array}{c}.001 \\
(.001)\end{array}$ \\
\hline County Republican Vote $_{t-1} \times$ DI & $\begin{array}{c}-.003^{*} \\
(.001)\end{array}$ & $\begin{array}{c}-.003^{*} \\
(.001)\end{array}$ \\
\hline Estimator & IV 2SLS & OLS \\
\hline $\mathrm{N}$ & 5,781 & 5,781 \\
\hline F-Test & $363^{*}$ & $515^{*}$ \\
\hline $\mathrm{R}^{2}$ & .480 & .514 \\
\hline
\end{tabular}

$* p \leq .05$ (two-tailed test). Robust standard errors cluster on county-election. Only elections with an incumbent president on the ballot are included. Election fixed effects are included. Democratic Incumbent $(D I)$ is not included in these models as it is subsumed by the election effects. 


\section{Estimating our IV model with Fuller's LIML approach}

Though diagnostics reveal that our instruments are not "weak," as a robustness check we also estimate our IV model (Model 3.1 in the manuscript) with an alternative estimator - Fuller's limited information maximum likelihood (Fuller 1977). Fuller's LIML is particularly robust in the face of weak instruments (see Andrews and Stock 2005; Hahn, Hausman, and Kuersteiner 2005) and thus it useful to consider the results obtained with this estimator. These results are presented on the next page. As with our IV 2SLS model, the estimate for Sociotropic Evaluation is positive and statistically significant while the estimate for Sociotropic Evaluation $\times$ Incumbent Candidate is negative and significant. Thus, the inferences drawn from this alternative estimator are fully consistent with those presented in Model 3.1, which further supports the conclusion that our IV model does not suffer from weak instruments.

\section{Additional References}

Andrews, Donald W.K., and James H. Stock. 2005. “Inference with Weak Instruments.” NBER Technical Working Paper No. 313.

Fuller, Wayne A. 1977. "Some Properties of a Modification of the Limited Information Maximum Likelihood Estimator.” Econometrica 45(4):939-954.

Hahn, Jinyong, Jerry Hausman, and Guido Kuersteiner. 2005. "Estimation with Weak Instruments: Accuracy of Higher Order Bias and MSE Approximations.” Econometrics Journal 7(1):272-306. 
TABLE A5. Fuller's LIML IV model of the effect of sociotropic evaluations on vote for incumbent president/party.

\begin{tabular}{|c|c|}
\hline Independent Variable & Model 4.1 \\
\hline Sociotropic Evaluation & $\begin{array}{c}.245^{*} \\
(.102)\end{array}$ \\
\hline Sociotropic Evaluation $\times$ Incumbent Candidate & $\begin{array}{l}-.321 * \\
(.136)\end{array}$ \\
\hline Party ID & $\begin{array}{l}.145^{*} \\
(.010)\end{array}$ \\
\hline Party ID $\times$ Democratic Incumbent (DI) & $\begin{array}{c}-.288^{*} \\
(.017)\end{array}$ \\
\hline Personal Income & $\begin{array}{l}.023^{*} \\
(.006)\end{array}$ \\
\hline Personal Income $\times$ DI & $\begin{array}{l}-.022^{*} \\
(.010)\end{array}$ \\
\hline Education & $\begin{array}{l}-.003 \\
(.004)\end{array}$ \\
\hline Education $\times$ DI & $\begin{array}{c}.002 \\
(.006)\end{array}$ \\
\hline Unemployed & $\begin{array}{c}-.060^{*} \\
(.020)\end{array}$ \\
\hline Unemployed $\times$ DI & $\begin{array}{c}.082^{*} \\
(.037)\end{array}$ \\
\hline Black & $\begin{array}{c}-.124^{*} \\
(.016)\end{array}$ \\
\hline Black $\times$ DI & $\begin{array}{c}.291 * \\
(.026)\end{array}$ \\
\hline Female & $\begin{array}{c}.015 \\
(.017)\end{array}$ \\
\hline Female $\times$ DI & $\begin{array}{c}.018 \\
(.021)\end{array}$ \\
\hline Age & $\begin{array}{l}.001 * \\
(.000)\end{array}$ \\
\hline Age $\times$ DI & $\begin{array}{c}-.001 \\
(.001)\end{array}$ \\
\hline County Republican Vote $_{t-1}$ & $\begin{array}{l}.002^{*} \\
(.000)\end{array}$ \\
\hline County Republican Vote $_{t-1} \times$ DI & $\begin{array}{c}-.003^{*} \\
(.001)\end{array}$ \\
\hline $\mathrm{N}$ & 9,568 \\
\hline F-Test & $413^{*}$ \\
\hline $\mathrm{R}^{2}$ & .436 \\
\hline
\end{tabular}

$* p \leq .05$ (two-tailed test). Alpha is set at four. Cell entries are coefficient estimates (and robust standard errors clustering on county-election). Election fixed effects are included. Democratic Incumbent and Incumbent Candidate are not included in these models as they are subsumed by the election effects. 


\section{Testing whether Incumbent Candidate conditions the effect of local conditions}

To test whether local objective economic conditions have a different effect on Sociotropic Evaluation when there is an incumbent president on the ballot, we estimate the model of Sociotropic Evaluation (Model 2.2 in the manuscript) while including $\Delta$ County Income $\times$ Incumbent Candidate and $\Delta$ County Unemployment $\times$ Incumbent Candidate. These results are presented on the next page. Neither of the estimates for these interaction terms are statistically significant, suggesting that the effect of local economic conditions on assessments of the national economy is not conditioned by the presence of a reelection-seeking president. 
TABLE A6. Effect of local objective conditions on sociotropic evaluations

Independent Variable

Model 2.2 (OLS)

$\Delta$ County Income $(\$ 1,000 \mathrm{~s})$

$.036^{*}$

$\Delta$ County Unemployment

(.013)

$-.043 *$

$\Delta$ County Income $\times$ Incumbent Candidate

(.011)

$\Delta$ County Unemployment $\times$ Incumbent Candidate

.005

(.023)

.018

(.013)

Party ID

$.145 *$

Party ID $\times$ Democratic Incumbent $(\mathrm{DI})$

(.006)

$-.254 *$

$(.010)$

Personal Income

.015

(.012)

Personal Income $\times$ DI

$-.022$

$(.023)$

Education

.011

(.007)

Education $\times$ DI

.003

(.013)

Unemployed

$-.075$

(.044)

Unemployed $\times$ DI

.091

(.096)

Black

$-.022$

(.046)

Black $\times$ DI

$-.041$

$(.080)$

Female

$-.202 *$

(.021)

Female $\times$ DI

$.152 *$

$(.041)$

$-.002 *$

Age

(.001)

Age $\times$ DI

$.005 *$

$(.001)$

County Republican Vote $_{t-1}$

.001

$(.001)$

County Republican Vote $_{t-1} \times$ DI

$-.003$

(.002)

9,568

F-Test

$231 *$

$\mathrm{R}^{2}$

.455

$* p \leq .05$ (two-tailed test). Cell entries are coefficient estimates (with robust standard errors allowing for clustering on county-election). Democratic Incumbent and Incumbent Candidate are not included in these models as they are subsumed by the election effects. 


\section{A Reduced-Form Model with Additional Elections}

To further probe the robustness of our IV results, we also estimate a single-stage reducedform model. $\Delta$ County Income is included directly in the main model predicting vote for the incumbent candidate/party. This reduced-form model does not require the sociotropic question, which allows us to add two more presidential elections to our data; 1972 and 1976. Due to data availability limitations, we cannot include $\Delta$ County Unemployment in this model.

This is a cautious move on our part-an attempt to give the retrospective voting hypothesis yet another test by allowing the exogenous changes in county income to substitute directly (i.e., proxy) for the individuals' subjective evaluations while increasing the number of elections (and observations). It is important to note that this model specification is not contradictory to our claim that local economic conditions satisfy the exclusion restriction in our IV models. $\Delta$ County Income can have a meaningful estimate as a proxy for subjective evaluations in this reduced form model while still not having an independent effect on vote choice. The results of this estimation are presented in Table A7.

The coefficient estimate for $\Delta$ County Income is positive and statistically significant, which is consistent with our IV results and the traditional models of retrospective voting. Assuming that increases in a county's median income cause a voter to believe that the national economy is improving, then increases in this subjective assessment lead a voter to be more likely to vote for the candidate from the president's party. But, when the president himself is on the ballot this retrospective effect goes away. The estimate for the interaction term is negative, significant, and of almost the exact same magnitude as the estimate for $\Delta$ County Income. Thus, when there is an incumbent presidential candidate the conditional coefficient for $\Delta$ County Income is effectively zero. This result is fully consistent with those of our IV models but diverges dramatically from those of the traditional models. 
TABLE A7. Reduced form model of the effect of sociotropic evaluations on vote for incumbent president/party, 1972 to 2008.

\begin{tabular}{|c|c|}
\hline Independent Variable & Model 5.1 \\
\hline$\Delta$ County Income $(\$ 1,000 \mathrm{~s})$ & $\begin{array}{c}.018^{*} \\
(.006)\end{array}$ \\
\hline$\Delta$ County Income $\times$ Incumbent Candidate & $\begin{array}{c}-.016^{*} \\
(.008)\end{array}$ \\
\hline Party ID & $\begin{array}{l}.139 * \\
(.002)\end{array}$ \\
\hline Party ID $\times$ Democratic Incumbent (DI) & $\begin{array}{c}-.287^{*} \\
(.004)\end{array}$ \\
\hline Personal Income & $\begin{array}{c}.020^{*} \\
(.004)\end{array}$ \\
\hline Personal Income $\times$ DI & $\begin{array}{c}-.018^{*} \\
(.008)\end{array}$ \\
\hline Education & $\begin{array}{c}-.007^{*} \\
(.003)\end{array}$ \\
\hline Education $\times$ DI & $\begin{array}{c}.006 \\
(.005)\end{array}$ \\
\hline Unemployed & $\begin{array}{c}-.046^{*} \\
(.014)\end{array}$ \\
\hline Unemployed $\times$ DI & $\begin{array}{c}.085^{*} \\
(.031)\end{array}$ \\
\hline Black & $\begin{array}{c}-.144^{*} \\
(.013)\end{array}$ \\
\hline Black $\times$ DI & $\begin{array}{c}.327^{*} \\
(.022)\end{array}$ \\
\hline Female & $\begin{array}{l}-.002 \\
(.008)\end{array}$ \\
\hline Female $\times$ DI & $\begin{array}{c}.050^{*} \\
(.015)\end{array}$ \\
\hline Age & $\begin{array}{c}.001 * \\
(.000)\end{array}$ \\
\hline Age $\times$ DI & $\begin{array}{l}-.001 \\
(.000)\end{array}$ \\
\hline County Republican Vote Vot-1 $_{1}$ & $\begin{array}{c}.002 * \\
(.000)\end{array}$ \\
\hline County Republican Vote $_{t-1} \times$ DI & $\begin{array}{c}-.004 * \\
(.001)\end{array}$ \\
\hline Election Fixed Effects? & Yes \\
\hline $\mathrm{N}$ & 12,561 \\
\hline F-Test & $583^{*}$ \\
\hline $\mathrm{R}^{2}$ & .488 \\
\hline
\end{tabular}

$* p \leq .05$ (two-tailed test). Cell entries are OLS estimates (with robust standard errors clustered on county-election). Incumbent Candidate and Democratic Incumbent are not included in the model as they are subsumed by the election effects. 